\title{
Ali Miransari. The Constitutional Revolution and Persian Dramatic Works: An Observation on Social Relations Criticism in the Plays of the Constitutional Era
}

Laetitia Nanquette (Bif)

\section{(2) OpenEdition}

Journals

Édition électronique

URL : http://journals.openedition.org/abstractairanica/40990

DOI : 10.4000/abstractairanica.40990

ISSN : 1961-960X

Éditeur :

CNRS (UMR 7528 Mondes iraniens et indiens), Éditions de l'IFRI

Édition imprimée

Date de publication : 1 décembre 2013

ISSN : 0240-8910

\section{Référence électronique}

Laetitia Nanquette (Bif), « Ali Miransari. The Constitutional Revolution and Persian Dramatic Works: An Observation on Social Relations Criticism in the Plays of the Constitutional Era », Abstracta Iranica [En ligne], Volume 32-33 | 2013, document 439, mis en ligne le 01 juillet 2016, consulté le 02 octobre 2020. URL : http://journals.openedition.org/abstractairanica/40990 ; DOI : https://doi.org/10.4000/ abstractairanica.40990

Ce document a été généré automatiquement le 2 octobre 2020.

Tous droits réservés 


\title{
Ali Miransari. The Constitutional Revolution and Persian Dramatic Works: An Observation on Social Relations Criticism in the Plays of the Constitutional Era
}

\author{
Laetitia Nanquette (Bif)
}

\section{RÉFÉRENCE}

Ali Miransari. « The Constitutional Revolution and Persian Dramatic Works: An Observation on Social Relations Criticism in the Plays of the Constitutional Era ", in : H. E. Chehabi and Vanessa Martin, eds., Iran's Constitutional Revolution. Popular Politics, Cultural Transformations and Transnational Connections. Traduit par H. E. Chehabi, London, I.B. Tauris, 2010, p. 239-248.

1 Ce chapitre d'un ouvrage consacré aux aspects socio-culturels de la révolution constitutionnelle traite d'un sujet peu étudié : le théâtre des années 1906 à 1911. L'A. affirme que l'aspect littéraire n'est pas dominant dans ces pièces de théâtre, et les décrit comme des instruments de critique sociale. Le chapitre commence par donner un aperçu de l'histoire du théâtre dans sa forme occidentale depuis 1850, avec les pièces de Fatḥ-'Alī ĀHūndzāde et Mīrzā Āqā Tabrīzī, qui les considéraient comme contribuant à la construction de la nation. Les dramaturges qui émergent après 1906 critiquent le climat sociopolitique du pays, qu'ils voient s'écarter des idéaux de la révolution constitutionnelle. L'A. s'intéresse plus particulièrement à des dramaturges dont la critique porte sur l'ensemble de la société mais dont les pièces peuvent être diffusées de façon variable. Celles d"Alī Hāan Zahīr al-Dowle ont par exemple été mises en scène, tandis que celles de Mīrzā Reḍa Nā'īnī et Moḥammad Reḍā Mosāvāt ont été publiées en 
feuilleton dans les journaux. L'A. se concentre en dernière partie sur la description de certaines pièces de Ẓahīr al-Dowle, Mīrzā Reḍā Nā’īnī, 'Abbās 'Alī As'adī et Mosāvāt.

\section{AUTEURS}

\section{LAETITIA NANQUETTE (BIF)}

Paris 